\title{
AMARANTHUS CRUENTUS L. AS A FOOD ALTERNATIVE IN LAYING HENS TO REDUCE CHOLESTEROL IN EGGS
}

\section{AMARANTHUS CRUENTUS L. COMO ALTERNATIVA ALIMENTARIA EN GALLINAS PONEDORAS PARA DISMINUIR EL COLESTEROL EN HUEVOS}

\author{
Hernán Rodríguez-Ríos ${ }^{1 *}$, Jorge Campos-Parra ${ }^{1}$, Rita Astudillo-Neira ${ }^{2}$, Jesús Grande-Cano ${ }^{3}$, Silvia \\ Carrillo-Domínguez ${ }^{4}$, Fernando Pérez Gil- Romo $^{49}$ \\ ${ }^{1}$ University of Concepción, Faculty of Agronomy, Department of Livestock Management, Avenida \\ Vicente Méndez 595, Chillán, Chile. herodrig@udec.cl., jcamposp@udec.cl. \\ ${ }^{2}$ University of Concepción, Faculty of Veterinary Medicine, Department of Animal Science, Avenida \\ Vicente Méndez 595, Chillán, Chile. riastudi@udec.cl. \\ ${ }^{3}$ Independent Metropolitan University Iztapalapa, Department of Agricultural Production Systems, \\ Av. San Rafael Atlixco No. 186, Col. Vicentina, Delegación Iztapalapa, C. P. 09340, Ciudad de México. \\ ifig@xanum.uam.mx. \\ ${ }^{4}$ Salvador Zubirán National Institute of Medical Science and Nutrition, Avenida Vasco de Quiroga No.15, \\ Colonia Belisario Domínguez Section XVI, Tlalpan Delegation C.P.14080, México. silviacarrillo3@ \\ hotmail.com. \\ *Corresponding author E-mail: herodrig@udec.cl
}

\section{RESUMEN}

El amaranto (Amaranthus cruentus L.) es un alimento de alto aporte en proteína, lisina y buen balance de aminoácidos. Además, ha demostrado ser eficiente para disminuir el colesterol del huevo. El objetivo de este estudio fue evaluar el efecto de diferentes niveles de inclusión de A. cruentus $\mathrm{L}$. en la dieta de aves de postura, sobre el contenido de colesterol en el huevo y parámetros productivos. Se realizó un experimento con 200 gallinas Hy Line de postura de 30 semanas de vida, para evaluar la inclusión de $A$. cruentus en proporciones de $0,15,30$ y $45 \%$ base materia seca. Durante 2 meses se evaluó el consumo semanal de alimento por ave, producción de huevos por semana, masa de huevo y conversión de alimento; 480 huevos fueron analizados para determinar el contenido de colesterol mediante cromatografía liquida de alto rendimiento. Los resultados fueron analizados mediante análisis de varianza en diseño de bloques al azar. La inclusión de semillas de $A$. cruentus en $15 \%$ de la ración disminuyó el colesterol en la yema de huevos, sin afectar significativamente los principales parámetros productivos.

Palabras clave: Amaranthus cruentus, amaranto, gallinas de postura, huevo, colesterol, nutrición.

\section{ABSTRACT}

Amaranth (Amaranthus cruentus L.) is a food high in protein and lysine content, and has a wellbalanced amino acid composition. In addition, it has shown to be efficient in lowering egg cholesterol. The objective of this study was to evaluate the effect of different inclusion levels of Amaranthus cruentus L. in the diet of laying hens, on egg cholesterol content and production parameters. 200 laying hens of 30 weeks of age were fed on diets that included $0,15,30$ and $45 \%$ (dry matter basis) of $A$. cruentus. For 2 months, weekly feed intake per hen, egg production per week, egg mass and 
feed conversion ratio were evaluated. 480 eggs were analyzed to determine cholesterol content by high performance liquid chromatography. The results were analyzed by analysis of variance for a randomized block design. The inclusion of $15 \%$ of $A$. cruentus seeds in the diet decreased egg yolk cholesterol content without significantly affecting the main production parameters.

Key words: Amaranthus cruentus, amaranth, laying hens, egg, cholesterol, nutrition.

\section{INTRODUCTION}

The majority of cardiovascular disease cases can be prevented by acting on behavioral risk factors, such as tobacco consumption, unbalanced diets, obesity, physical inactivity, or excessive alcohol consumption (GBD, 2015; OMS, 2015) and cholesterol consumption. The American Heart Association limited consumption to a maximum of three eggs per week, but that recommendation has now been replaced by seven eggs per week (Saleh, 2019), with a dietary cholesterol intake of less than $300 \mathrm{mg} \mathrm{d}^{-1}$. Since a single large egg contains $\sim 210 \mathrm{mg}$ of cholesterol per unit $\sim 71 \%$ of the recommended daily value), it is recommended to restrict egg consumption to one unit per day (Kraus et al., 2000; Soriano-Maldonado et al., 2013; Fuentes 2016).

The factors that modify egg cholesterol content are: genetics (although cholesterol content has a low rate of heritability), the use of pharmaceuticals (administering hypocholesterolemic drugs to hen lowers egg cholesterol), management (as the age of the laying hen increases, so does egg cholesterol), and nutrition (changes in diet can modify cholesterol content and egg production) (Elkin, 2007).

Among the vegetable-based alimentary alternatives used in hen feed for reducing cholesterol are black cumin (Nigella sativa L.) (Aydin et al., 2008), squash (Cucurbita maxima Duchesne) (Martinez et al., 2012), rapeseed (Brassica napus L.) (Caston and Leedon 1990), chia (Salvia hispanica L.) (Salazar-Vega et al., 2009), soy (Glycine max L.), sunflower seed (Helianthus annuus L.) (Shin et al., 2012) and the marine algae Sargassum spp. (Carrillo et al., 2012).

Amaranth (Amarantus cruentus L.) could also be used as alternative to achieve the same goal. Several agents capable of reducing cholesterol have been found in amaranth, such as dietary fiber, squalene, tocotrienols and sterols (beta-sitosterol, campesterol, estigmasterol) (Morales et al., 2009). Some researchers have used levels of 2.5 to $30 \%$ of amaranth seed in the diets of laying hens in order to evaluate its effect on various productive and biochemical variables (Bartkowiak et al., 2007; Króliczewska et al., 2008; Popiela et al., 2013). Moreover, amaranth seed is an excellent source of protein (13-22\%) and lysine (0.73-0.84\%) and balance of amino acids, which could replace part of the corn and soybean meal used in poultry feed. In addition, when amaranth is processed under conditions that do not damage the availability of essential amino acids, its protein quality is very similar to that of casein, a protein whose effect on feed intake and weight gain of animals has been well documented (Morales et al., 2009). Peiretti (2018) has indicated that amaranth grain, which has about twice the amount of protein as cereal grains, a superior amino acid composition and similar energy content, can be used as a feed ingredient for broilers, and it should only be included as raw material in finisher diets. In fact, a heat treatment, in the form of autoclaving, extrusion, atmospheric cooking, toasting or popping, is usually necessary to partially or completely destroy its growth depressing factors for growing chickens.

The objective of this study was to evaluate the effect of different inclusion levels of Amaranthus cruentus L. in the diet of laying hens, on egg cholesterol content and production parameters.

\section{MATERIALS AND METHODS}

\section{Amaranth seed collection and processing}

Amaranth (A. cruentus) was sown at the experimental station of the Faculty of Agronomy at the University of Concepción, Chillán, Chile $\left(36^{\circ} 26^{\prime} \mathrm{S} ; 72^{\circ} 06^{\prime} \mathrm{W}\right)$, at 144 masl in a Diguillin soil series. The sowing rate was $7.5 \mathrm{~kg} \mathrm{ha}^{-1}$ during spring. The management practices conducted included plant thinning, application of fertilizers, irrigation and application of a desiccant during seed maturation in order to obtain a higher quality seed. After harvest, seeds were processed in a hammer mill (Wetmore, Madison, Wisconsin, USA) until apt for inclusion in hen feed. Amaranth was thermally treated in a vertical autoclave (AESA, model CV-250, Mexico City, Mexico), for $45 \mathrm{~min}$ at $110^{\circ} \mathrm{C}$ and 0.5 atmospheres (atm) in order to eliminate the anti-trypsinogen content (Waldroup and Tillman, 1986; Kabuage et al., 2002, Peiretti 2018). The elimination of the anti-trypsinogen content was necessary for the inclusion of amaranth in hen feed. The chemical composition and amino acid content of the thermally treated amaranth is shown in Table 1 and Table 2, respectively. 
Table 1. Chemical composition (dry matter basis) of thermally treated amaranth seed (Amaranthus cruentus).

\begin{tabular}{lr}
\hline Nutrient & \% \\
\hline Dry matter & 92.5 \\
Ash & 3.7 \\
Ether extract & 6.0 \\
Crude protein & 15.4 \\
Crude fiber & 4.3 \\
Calcium & 0.3 \\
Available phosphorus & 0.1 \\
Lysine & 0.8 \\
Methionine + Cystine & 0.7 \\
Metabolizable energy (ME) $\left(\mathrm{kcal} \mathrm{kg}^{-1}\right)$ & 3100 \\
\hline
\end{tabular}

Source: Laboratory of the Faculty of Agronomy, University of Concepción.

Table 2. Amino acid content (dry matter basis) of thermally treated amaranth (Amaranthus cruentus) seed.

\begin{tabular}{lc}
\hline Amino acids & g $\mathbf{1 0 0}$ g protein $^{-1}$ \\
\hline Aspartic Acid & 6.0 \\
Glutamic Acid & 14.0 \\
Serine & 5.0 \\
Glycine & 8.0 \\
Histidine & 2.0 \\
Arginine & 8.0 \\
Threonine & 3.0 \\
Alanine & 2.0 \\
Proline & 6.0 \\
Tyrosine & 6.0 \\
Valine & 6.0 \\
Methionine & 3.0 \\
Isoleucine & 6.0 \\
Leucine & 6.0 \\
Phenylalanine & 8.0 \\
Lysine & 8.0
\end{tabular}

Source: Laboratory of the Faculty of Agronomy, University of Concepción.

\section{Inclusion of amaranth seed}

The trial was conducted using laying hens for a period of two months at the poultry farm located in the Experimental Station of the Faculty of Agronomy (campus Chillán) of the University of Concepción. This poultry farm was kept under veterinary supervision throughout the experimental period. In all cases, the diets were calculated based on the requirements of the National Research Council (NRC, 1994). From a total of 2000 hens, of 30 weeks of age, line Hy Line, 200 hens $(10 \%)$ were randomly selected for the experiment, and divided into 4 treatments and 5 replicates $(n=10)$. The hens were kept in conventional battery cages and feed and water were provided ad libitum. The feed (Table 3) included corn, wheat bran, soybean meal, calcium carbonate, DL-methionine, vitamin and mineral mix and common salt, and was modified in its main ingredients to include $A$. cruentus in rates of levels of $0,15,30$ and $45 \%$.

\section{Egg yolk cholesterol content}

For seven days, eggs were collected per treatment replicates, stored at $23^{\circ} \mathrm{C}$ and $50 \%$ $\mathrm{RH}$. Of the total eggs collected, 24 eggs were 
randomly selected per replicate, with a total of 480 eggs for analysis of egg yolk cholesterol content per week. The yolk was separated from the egg albumin and cholesterol content of the fresh yolk was determined using the technique described by Elswyk et al. (1991) and modified by Figueroa et al. (2002). A high-performance liquid chromatography (HPTLC) with an automated multiple development (AMD) chamber was used (Merck KgaA, Darmstad Germany).

\section{Production variables}

During the experiment, the following production variables were evaluated: weekly feed consumption (g week ${ }^{-1}$ hen $^{-1}$ ) and egg production (dozen week $\left.{ }^{-1}\right)$. Egg mass (g eggs hen ${ }^{-1}$ day $^{-1}$ ) and feed conversion ( $\mathrm{kg}$ feed dozen eggs ${ }^{-1}$ ) were also calculated, considering the total hens of the experiment.

\section{Statistical analysis}

An analysis of variance for randomized block design was used. For mean comparison, the Duncan test was used with a significance level of 0.05 ( $\mathrm{P} \leq 0.05$ ) (Balzarini et al., 2008), using the statistical program InfoStat (Di Rienzo et al., 2008).

\section{RESULTS AND DISCUSSION}

\section{Egg yolk cholesterol content}

The average value for egg yolk cholesterol content of the treatment with $0 \%$ amaranth inclusion was $349.13 \mathrm{mg}$ g egg yolk ${ }^{-1}$. This value was not significantly different $(\mathrm{P}>0.05)$ from the remaining treatments including amaranth seeds in the diet (Table 4). These results should be confirmed with more experiments in order to evaluate a greater range of concentrations and consider other reasons for variation.

The relationship between laying percentage and cholesterol content according to different inclusion levels of amaranth is shown in Fig. 1. Considering the $0 \%$ inclusion treatment as the baseline level to improve (decrease), it is observed that the most pronounced decrease occurs in the treatment with $15 \%$ amaranth inclusion, while the treatment with $45 \%$ inclusion presented the lowest delta of cholesterol decrease, which was associated with higher laying percentages. Treatments with 30 and $45 \%$ inclusion of amaranth resulted in a decrease in egg yolk cholesterol levels; the hens in these treatments had greater feed intake, but this was not reflected in a higher egg production. With regard to egg yolk cholesterol content, the results obtained in

Table 3. Ingredients and nutritional composition of the diets with different inclusion levels of amaranth (Amaranthus cruentus) seeds used in experiment of laying hens.

\begin{tabular}{lrrrr}
\hline & \multicolumn{4}{c}{ Amaranth inclusion (\%) } \\
\hline Ingredients ( kg 1000 kg diet ${ }^{-1}$ ) & 0 & 15 & 30 & 45 \\
\hline Corn & 690 & 578 & 460 & 342 \\
Amaranth & 0 & 150 & 300 & 450 \\
Soybean meal & 238 & 200 & 168 & 136 \\
Oyster shells & 60 & 60 & 60 & 60 \\
Salt & 2 & 2 & 2 & 2 \\
Tricalcium phosphate & 9 & 9 & 9 & 9 \\
Vitamin and mineral mix ${ }^{1}$ & 1 & 1 & 1 & 1 \\
Total $\quad 1000$ & 1000 & 1000 & 1000 \\
\hline \multicolumn{1}{c}{ Nutrients } & & & & \\
\hline Metabolizable energy (kcal kg-1) & 2847 & 2850 & 2850 & 2850 \\
Crude protein (\%) & 16.4 & 16.0 & 16.0 & 16.0 \\
Total Met + Cys ${ }^{2}$ (\%) & 0.57 & 0.60 & 0.62 & 0.65 \\
Total Lysine (\%) & 0.84 & 0.94 & 1.06 & 1.18 \\
Total Calcium (\%) & 2.42 & 2.45 & 2.47 & 2.50 \\
Available Phosphorus (\%) & 0.32 & 0.32 & 0.32 & 0.32 \\
\hline
\end{tabular}

${ }^{1}$ Vitamin and mineral mix (per $1000 \mathrm{~kg}$ of feed): Vitamin A 8000000 UI, Vitamin D3 3300000 UI, Vitamin E 20 g, Vitamin K 2.5 g, Vitamin B1 2.5 g, Vitamin B2 5.5 g, Vitamin B3 30 g, Vitamin B5 8g, Vitamin B6 4 g, Vitamin B7 75 mg, Vitamin B9 0.9 g, Vitamin B12 23 mg, Choline 110 g, Zinc 80 g, Iron 40 g, Copper 8 g, Iodine $1.2 \mathrm{~g}$, Selenium $0.22 \mathrm{~g},{ }^{2}$ Total Met+Cys (\%): total Methionine and Cysteine.

Source: Laboratory of the Faculty of Agronomy, University of Concepción. 
Table 4. Average egg yolk cholesterol content of laying hens fed on diets with different inclusion levels of amaranth (Amaranthus cruentus ) seeds (mg g egg yolk ${ }^{-1}$ ) during the 8-week study period.

\begin{tabular}{cccccccccc}
\hline Amaranth & \multicolumn{8}{c}{ Week } \\
\cline { 2 - 9 } inclusion & $\mathbf{1}^{\circ}$ & $\mathbf{2}^{\circ}$ & $\mathbf{3}^{\circ}$ & $\mathbf{4}^{\circ}$ & $\mathbf{5}^{\circ}$ & $\mathbf{6}^{\circ}$ & $\mathbf{7}^{\circ}$ & $\mathbf{8}^{\circ}$ & Mean \\
\hline $0 \%$ & 315 & 370 & 409 & 378 & 322 & 302 & 354 & 343 & $349.13 \mathrm{a}$ \\
$15 \%$ & 288 & 285 & 275 & 367 & 362 & 341 & 340 & 273 & $316.38 \mathrm{a}$ \\
$30 \%$ & 263 & 363 & 298 & 359 & 276 & 316 & 392 & 372 & $329.88 \mathrm{a}$ \\
$45 \%$ & 317 & 397 & 297 & 381 & 360 & 304 & 366 & 286 & $338.50 \mathrm{a}$ \\
\hline $\mathrm{CV} \%$ & & & & & & & & & 12.54
\end{tabular}

Means with the same letter within a row do not differ significantly (Duncan test $\mathrm{P} \leq 0.05$ ).

$\mathrm{CV}$ : coefficient of variation.

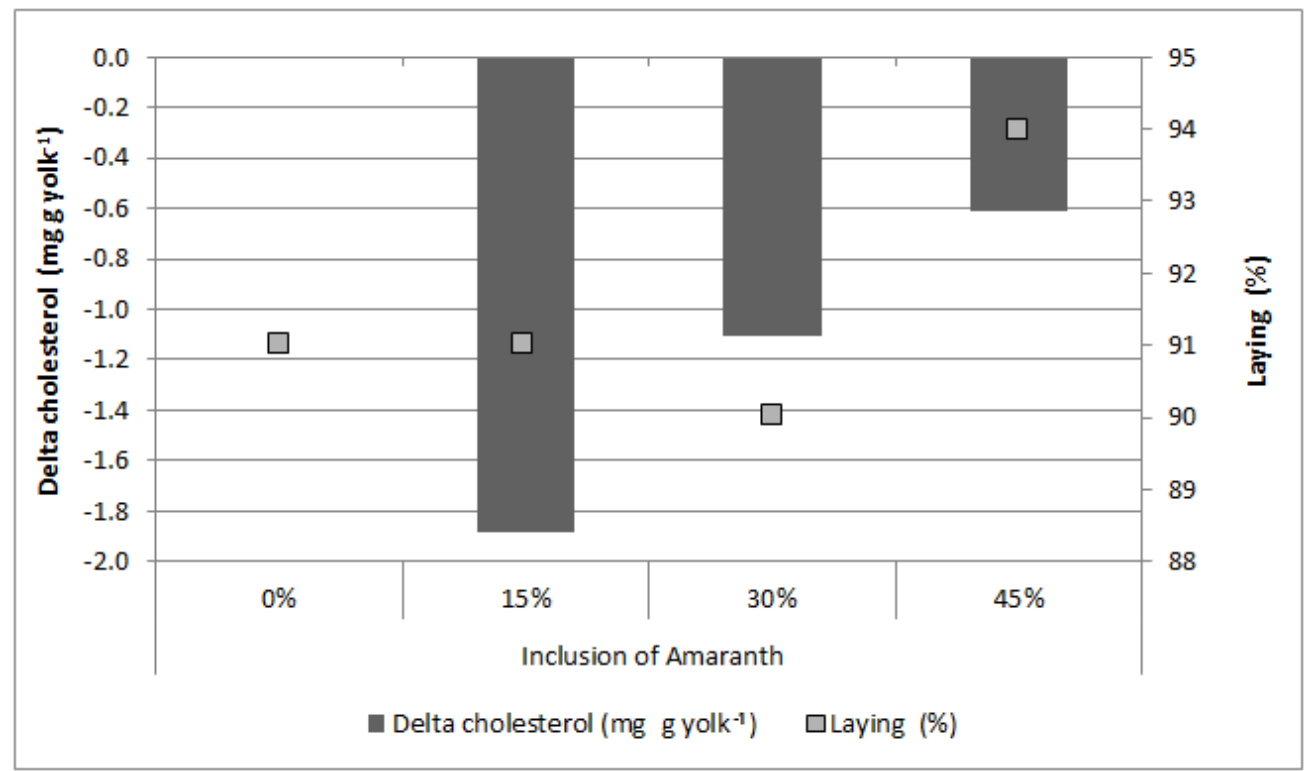

Fig. 1. Delta of the average values for egg yolk cholesterol content ( $\left.\mathrm{mg} \mathrm{g} \mathrm{yolk}^{-1}\right)$ during the 8-week study period.

the experiment differ from the findings of Punita and Chaturvedi (2000), who observed a $14 \%$ reduction in cholesterol content when amaranth was added to chicken food.

\section{Egg production}

The inclusion of amaranth seeds affected mean egg production (laying percentage) ( $\mathrm{P}$ $<0.05$ ) (Table 5). The treatments with 0, 15 and $30 \%$ inclusion of amaranth seeds did not differ between them, being statistically lower than the treatment with $45 \%$ inclusion. The laying percentage indicated by Hy Line International, for hens between 30 and 37 weeks of age, varies between 92 and $96 \%$; therefore, the values of the experiment would be below the commercial line standard (Hy Line International, 2018). This should not be attributed to the contribution of energy and protein from the diet, since it meets the requirements of the commercial line (Table 3 ). However, values obtained are similar to those reported by Popiela et al (2013) with inclusions of 5 and $10 \%$ of extruded amaranth grains in a total of 60 Lohmann Brown laying hens of 24 weeks of age. The egg-mass average values obtained during the 8 week-period were 50, 52, 52 and $53 \mathrm{~g}$ eggs hen ${ }^{-1}$ day $^{-1}$ for the $0,15,30,40 \%$ treatments, respectively, with no statistical differences among the treatment groups $(\mathrm{P}>0.05)$. The results obtained differed from the findings of Tillman and Waldroup (1987). They reported an increase in egg production when amaranth seed made up 10 and $20 \%$ in the feed of laying hens, a slight decrease in food intake of 10 and $30 \%$, an improved 
feed conversion rate in the three treatments that included amaranth, and no change in egg mass compared to the control. However, egg weight was significantly lower in treatments including amaranth seed. The reduction of feed intake that they observed was attributed to the possible presence of undesirable elements in amaranth seed that were not destroyed by extrusion.

\section{Feed intake and feed conversion ratio}

Hen feed intake fluctuated from $108 \mathrm{~g}$ hen $^{-1}$ day $^{-1}$ in the control to $121 \mathrm{~g}^{-1}$ day $^{-1}$ for the treatment with $45 \%$ of amaranth. As the amount of amaranth in the feed increased, the feed intake also increased, with significant statistical differences $(\mathrm{P}<0.05)$ (Table 6). Feed intake values are below those reported by Popiela et al. (2013); values varied between 148 and $152 \mathrm{~g} \mathrm{hen}^{-1} \mathrm{day}^{-1}$, but this can be attributed to the use of different bird races between studies. The feed conversion ratio was inversely proportional to the inclusion of amaranth in the diet $(P \leq 0.05)$ (Table 6), ranging between 1.44 and $1.58 \mathrm{~kg}$ feed egg dozen $^{-1}$. A higher conversion rate was observed in the treatment with $30 \%$ amaranth inclusion, which also corresponds to the treatment with the lowest laying percentage.

\section{CONCLUSIONS}

Based on the information obtained, it can be concluded that the inclusion of up to $45 \%$ of amaranth seeds did not affect egg yolk cholesterol content, but affected significantly the laying percentage, feed intake and feed conversion ratio.

\section{LITERATURE CITED}

American Heart Association. 2014. Good vs. bad cholesterol. Available on line http://www.heart.org/HEARTORG/ Conditions/Cholesterol/AboutCholesterol/ GoodvsBadCholesterol_UCM_305561_ Article.jsp\# (Accessed 2 November 2015).

Aydin R., M. Karaman, T. Cicek, and H. Yardibi. 2008. Black cumin (Nigella sativa L.) supplementation into the diet of the laying hen positively influences egg yield parameters, shell quality, and decreases egg cholesterol. Poult. Sci. 87:2590-2595.

Balzarini, M.G., L.A. González, E.M. Tablada, F. Casanoves, J.A. Di Rienzo, y C.W. Robledo, 2008. Infostat: software estadístico. Manual del Usuario. Versión 1. Brujas Argentina, Córdoba, Argentina.

Table 5. Weekly egg production (\%) of laying hens fed on diets with different levels of amaranth seeds (Amaranthus cruentus).

\begin{tabular}{cccccccccc}
\hline Amaranth & \multicolumn{8}{c}{ Laying percentage (\%) per week } \\
\cline { 2 - 10 } inclusion & $\mathbf{1}^{\circ}$ & $\mathbf{2}^{\circ}$ & $\mathbf{3}^{\circ}$ & $\mathbf{4}^{\circ}$ & $\mathbf{5}^{\circ}$ & $\mathbf{6}^{\circ}$ & $\mathbf{7}^{\circ}$ & $\mathbf{8}^{\circ}$ & Mean \\
\hline $0 \%$ & 95 & 91 & 93 & 92 & 90 & 90 & 89 & 89 & $91.13 \mathrm{~b}$ \\
$15 \%$ & 95 & 94 & 93 & 90 & 92 & 88 & 89 & 89 & $91.25 \mathrm{~b}$ \\
$30 \%$ & 91 & 89 & 90 & 92 & 92 & 87 & 91 & 90 & $90.25 \mathrm{~b}$ \\
$45 \%$ & 95 & 95 & 92 & 93 & 94 & 94 & 93 & 94 & $93.75 \mathrm{a}$ \\
\hline $\mathrm{CV} \%$ & & 8 & & & & & & 2.12 \\
\hline
\end{tabular}

Means with the same letter within a row do not differ significantly (Duncan test $\mathrm{P} \leq 0.05)$. CV: coefficient of variation.

Table 6. Average feed intake and feed conversion ratio of laying hens during the 8-week study period.

\begin{tabular}{ccc}
\hline Inclusion of amaranth & $\begin{array}{c}\text { Feed intake } \\
\left(\mathbf{g ~ h e n ~}^{-1} \text { day }^{-1}\right)\end{array}$ & $\begin{array}{c}\text { Feed conversion ratio } \\
\left.\text { (kg feed egg dozen }^{-1}\right)\end{array}$ \\
\hline $0 \%$ & $107.50 \mathrm{c}$ & $1.44 \mathrm{~b}$ \\
$15 \%$ & $113.63 \mathrm{~b}$ & $1.49 \mathrm{ab}$ \\
$30 \%$ & $117.75 \mathrm{ab}$ & $1.58 \mathrm{a}$ \\
$45 \%$ & $120.63 \mathrm{a}$ & $1.55 \mathrm{a}$ \\
\hline $\mathrm{CV}$ & 4.77 & 5.89 \\
\hline
\end{tabular}

Means with the same letter within a row do not differ significantly (Duncan test $\mathrm{P} \leq 0.05$ ).

$\mathrm{CV}$ : coefficient of variation. 
Bartkowiak A., T. Skiba, and B. Króliczewska. 2007. Level of selected lipid fractions in egg yolk of hens fed with fooders supplemented with amaranth seeds. Pol. J. Food Nutr. Sci. 57(4A):3-6.

Carrillo D.S., A. Bahena, V.M. Casas, J.M.E. Carranco, C.C. Calvo, G.E. Ávila, et al. 2012. The marine algae Sargassum spp. as an alternative for reducing the cholesterol content of eggs. Cuban J. Agric. Sci. 46(2):1-6.

Caston L., and S. Leeson. 1990. Dietary flax and egg composition. Poult. Sci. 2:1617-1620.

Di Rienzo J.A., F. Casanoves, M.G. Balzarini, L. M. Gonzalez, Tablada, y C.W. Robledo 2008. InfoStat, versión 2008. Grupo InfoStat, FCA, Universidad Nacional de Córdoba, Argentina.

Elkin, R.G. 2007. Reducing shell egg cholesterol content. II. Review of approaches utilizing non-nutritive dietary factors or pharmacological agents and an examination of emerging strategies. World's Poult. Sci. J. 62:5-32.

Elswyk, M.E., L.S. Schake, and P.S. Hargis. 1991. Evaluation of two extraction methods for the determination of egg yolk cholesterol. Poult. Sci. 70(5):1258-1260.

Figueroa C., M. Vega, R. Saelzer, G. Ríos y H. Rodríguez. 2002. Análisis de la fracción lipídica de la yema de huevos por AMDHPTLC. Bol. Soc. Chil. Quím. 47(1):61-66. Available on line http://dx.doi.org/10.4067/ S0366-16442002000100011 (Accessed 2 November 2015).

Fuentes García, A., 2016. Consumo de huevos y riesgo cardiovascular. Nutr Hosp. 33(Supl. 4):41-43. Disponible en http://dx.doi. org/10.20960/nh.344. (Consulta 28 enero 2020).

GBD. 2015. Global, regional, and national agesex specific all-cause and cause-specific mortality for 240 causes of death, 1990-2013: a systematic analysis for the Global Burden of Disease Study 2013. Lancet 385:117-171.

Grobas S., and G.G. Mateos. 1996. Influencia de la nutrición sobre la composición nutricional del huevo. XII Curso de Especialización FEDNA. Madrid 7 y 8 de noviembre de 1996. Disponible en https://www.researchgate. net/publication/28180440_ Influencia de la nutrición sobre la composición nutricional del huevo. (Consulta 2 noviembre 2015).

Hy Line International. 2018. Guía de manejo. Ponedoras comerciales W-36. Disponible en https://www.hyline.com/userdocs/pages/36 COM_SPN.pdf. (Consulta 20 enero 2020)
Instituto de Estudios del Huevo. 2009. El gran libro del huevo. $1^{\underline{a}}$ ed. Editorial Everest, León, España. Disponible en http://www. institutohuevo.com/images/archivos/ el_gran_libro_del_huevo.pdf. (Consulta 2 noviembre 2015).

Kabuage L.W., P.N. Mbugua1, B.N. Mitaru, T.A. Ngatia and K. Schafer. 2002. Effect of fortifying amaranth diets with amino acids, casein and ethylene diamine tetra acetate on broiler performance, amino acid availability and mineral utilization. South African Journal of Animal Science 32 (2).

Krauss R.M., Eckel R.H., Howard B., et al. 2000. AHA Dietary Guidelines. Revision 2000: A statement for Healthcare Professionals from the Nutrition Committee of the American Heart Association. Circulation 102:2284-2299.

Króliczewska B., W. Zawadski, A. Bartkowiak, and T. Skiba. 2008. The level of selected blood indicators of laying hens fed with addition of amaranth grain. Electronic J. Polish Agric. Univ. 11(2), art-18. Available on line http:// www.ejpau.media.pl/volume11/issue2/art18.html. (Accessed 6 February 2016).

Martínez Y., M. Valdivié, G. Solano, M. Estarrón, O. Martínez, y J. Córdova. 2012. Efecto de la harina de semilla de calabaza (Cucurbita maxima) en el colesterol total y ácidos grasos de los huevos de gallinas ponedoras. Revista Cubana de Ciencia Agrícola 46(1):73-78.

Morales G.J.C., M.N. Vázquez, y C.R. Bressani. 2009. El Amaranto: características físicas, químicas, toxicológicas, funcionales y aporte nutricio. 269 p. Instituto Nacional de Ciencias Médicas y Nutrición Salvador Zubirán. México D.F.

NRC. 1994. Nutrient Requirements of Poultry. 9th rev. ed. National Research Council, Washington, D.C., USA

OMS. 2015. Enfermedades cardiovasculares. Nota descriptiva enero 2015. Organización Mundial de la Salud (OMS). Disponible en http://www.who.int/mediacentre/factsheets /fs317/es/. (Consulta 03 septiembre 2016).

Peiretti, P.G. 2018. Amaranth in animal nutrition: A review. Livestock Research for Rural Development Volume 30, Article \#88. Available on line http://www.lrrd.org/ lrrd30/5/peir30088.html. (Accessed 21 January 2020).

Popiela E., B. Króliczewska, and W. Zawadski. 2013. Effect of extruded amaranth grains on performance, egg traits, fatty acids composition, and selected blood characteristics of laying hens. Livestock Sci. 155:308-315. 
Punita A. and A. Chaturvedi. 2000. Effect of feeding crude red palm oil (Elaeis guineensis) and grain amaranth (Amaranthus paniculatus) to hens on total lipids, cholesterol, PUFA levels and acceptability of eggs. Plant Foods Human Nutrition 55(2):147-157.

Salazar-Vega M.I., J.G. Rosado-Rubio, L.A. Chel-Guerrero, D.A. Betancur-Ancona, A.F. Castellanos-Ruelas. 2009. Composición en ácido graso alfa linolénico $(\omega 3)$ en huevo y carne de aves empleando Chia (Salvia hispanica 1.) en el alimento. Interciencia 34(3):209-213.

Saleh, N. 2019. Eggs: Healthy or not? Here's the latest research. Available at https://www. mdlinx.com/internal-medicine/article/3683 (Accessed 12 December 2019)

Shin S.R., J. Lu, H.B.Tong, J.M. Zou, and K.H. Wang. 2012. Effects of graded replacement of soybean meal by sunflower seed meal in laying hen diets on hen performance, egg quality, egg fatty acid composition, and cholesterol content. J. Appl. Poult. Res. 21:367-374.
Soriano-Maldonado A., M. Cuenca-García, L.A. Moreno, M. González-Gross, C. Leclercq, O. Androutsos, et al. . 2013. Ingesta de huevo y factores de riesgo cardiovascular en adolescentes; papel de la actividad física. Estudio HELENA. Nutr. Hosp. 28(3):868-877.

Tillman P.B., and P.W. Waldroup. 1987. Effects of feeding extruded grain amaranth to laying hens. Poult. Sci. 66(10):1697-1701.

Waldroup P.W., and P.B. Tillman. 1986. Processing grain amaranth for use in broilers diet. Poult. Sci. 65:1960-1964. 